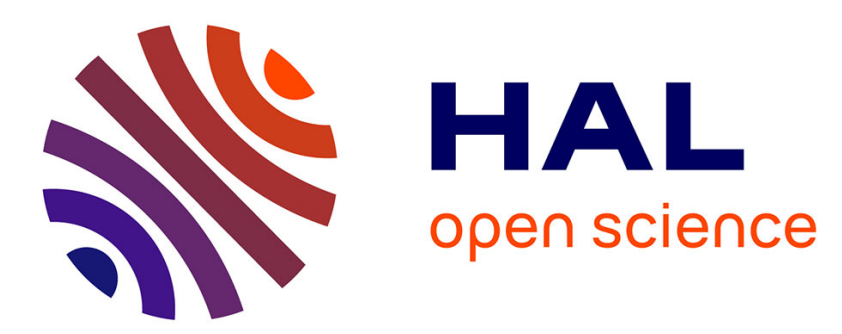

\title{
Bank credit and short-run economic growth: a dynamic threshold panel model for ASEAN countries
}

\author{
Sy-Hoa Ho, Jamel Saadaoui
}

\section{To cite this version:}

Sy-Hoa Ho, Jamel Saadaoui. Bank credit and short-run economic growth : a dynamic threshold panel model for ASEAN countries. 2020. hal-03008069

\section{HAL Id: hal-03008069 \\ https://hal.science/hal-03008069}

Preprint submitted on 16 Nov 2020

HAL is a multi-disciplinary open access archive for the deposit and dissemination of scientific research documents, whether they are published or not. The documents may come from teaching and research institutions in France or abroad, or from public or private research centers.
L'archive ouverte pluridisciplinaire HAL, est destinée au dépôt et à la diffusion de documents scientifiques de niveau recherche, publiés ou non, émanant des établissements d'enseignement et de recherche français ou étrangers, des laboratoires publics ou privés. 

countries»

\author{
$\underline{\text { Auteurs }}$ \\ Sy-Hoa Ho, Jamel Saadaoui \\ Document de Travail n $2020-48$
}

Novembre 2020

Théorique et Appliquée BETA

www.beta-umr7522.fr

@ @beta_economics

Contact :

jaoulgrammare@beta-cnrs.unistra.fr 


\title{
Bank credit and short-run economic growth: a dynamic threshold panel model for ASEAN countries
}

\author{
Sy-Hoa $\mathrm{Ho}^{\mathrm{a}, *}$, Jamel Saadaoui ${ }^{\mathrm{b}, * *}$ \\ ${ }^{a}$ Institute of Research and Development, Duy-Tan University; TIMAS - Thang-Long University, Vietnam \\ ${ }^{b}$ University of Strasbourg, University of Lorraine, BETA, CNRS, 67000, Strasbourg, France
}

\begin{abstract}
We investigate short-run nonlinear impacts of bank credit on economic growth in ASEAN countries. We find an inverted L-shaped relationship and a statistically significant threshold of $96.5 \%$. Positive effects of bank credit expansion on short-run economic growth fade away after this threshold.
\end{abstract}

Keywords: Bank credit, Economic growth, Dynamic threshold estimation, ASEAN JEL: C23, E51, G21, O41

\section{Introduction}

In a recent contribution, Lay (2020) explores the possibility of threshold effects in the relationship between bank credit and short run economic growth. In his empirical investigation, an inverted U-shaped relationship is identified, and a threshold of 135\% of GDP is found after World War II in 17 industrialized countries. Simply put, when the credit-to-GDP ratio is above $135 \%$, a further bank credit expansion is detrimental to economic growth. Until this threshold, bank credit expansion has a positive effect on economic growth in the short run.

Our empirical investigation focuses on ASEAN countries over the period spanning from 1993 to 2019. Indeed, there are several reasons that lead us to think that we could not make

\footnotetext{
*Corresponding author

** Principal corresponding author

Email addresses: hosyhoa1@duytan.edu.vn (Sy-Hoa Ho), saadaoui@unistra.fr (Jamel Saadaoui)

URL: www . jamelsaadaoui.com (Jamel Saadaoui)
} 
a reliable statistical inference for ASEAN countries form the empirical evidence provided for industrialized countries after World War II (i.e. differences in the level of development, differences in the level of financial development and financial openness). In our empirical investigation, we find an inverted L-shaped relationship between bank credit and short run economic growth and a statistically and significant threshold of $96.5 \%$ for the credit-to-GDP ratio. Positive effects of bank credit expansion on short-run economic growth fade away after this threshold.

In addition to the empirical study of Lay (2020), few studies have explored the relationship between bank credit and economic growth in the short run. Loayza and Ranciere (2006) use a panel data error-correction model that allows for short-run heterogeneity and long run homogeneity. They also use a linear dynamic panel data model to investigate this question, but do not investigate regional differences and the existence of threshold effects. Narayan and Narayan (2013) explore regional differences in a linear dynamic panel data model and, thus, cannot detect the existence of threshold effects. In the following section, we detail the methodology used to estimate the threshold in a dynamic panel data model with endogenous regressors. Then, we present the empirical results in the third section. Finally, we conclude in the last section.

\section{Methodology}

We follow the approach of Kremer et al. (2013). In their approach, they combine the panel threshold model of Hansen (1999) and the instrumental variable estimation of the crosssectional model introduced by Caner and Hansen (2004) thanks to the application of the forward orthogonal deviations transformation suggested by Arellano and Bover (1995). This approach has several advantages, firstly, we can estimate threshold values rather than impose them as rightly underlined by Hansen (1999), secondly, we can use a dynamic panel data model where endogeneity of important control variables is no longer an issue and, finally, by 
eliminating the fixed effects thanks to forward orthogonal deviations, this approach ensures that the error terms remain uncorrelated.

Thus, we follow Kremer et al. (2013), Lay (2020) and Baum et al. (2013) to investigate the possibility of threshold effects in the relationship between bank credit and short run economic growth. To this aim, we consider the following panel threshold model:

$$
y_{i t}=\mu_{i}+\chi y_{i, t-1}+\beta_{1} f_{i t} I\left(f_{i t} \leq \gamma\right)+\beta_{2} f_{i t} I\left(f_{i t}>\gamma\right)+\alpha_{1} X_{i t}+\varepsilon_{i t}
$$

where subscripts $i=1, \ldots, n$ represents the country and $t=1, \ldots, T$ index the time. $\mu_{i}$ is the country-specific fixed effect, and the error term is $\varepsilon_{i t} . y$, is the annual GDP per capita growth rate and $I($.$) is an indicator function indicating the regime defined by the threshold$ variable, $f$, the credit-to-GDP ratio. Here, the threshold variable and the regime dependent variable are the same, the credit-to-GDP ratio, as we can see in equation (1). The independent regime control variables, $X$ include the investment, $I N V$, the government expenditure, $G O V$, the consumer price index, INFLATION, and the population, $P O P$, all four measured in annual percentage growth, but also, the terms of trade, TOT, the openness ratio, OPEN, and dummy variables, BANKING, CURRENCY, DEBT and RESTRUCTURING for banking crises, currency crises, sovereign debt crises and debt restructuring, respectively.

The dynamic version of the model ${ }^{1}$ in equation (1) is estimated in three steps:

1. In the first step, we estimate a reduced form of the endogenous variable, $y_{i, t-1}$, as a function of the instruments on a set of regressors restricted to 1 lag since instruments ${ }^{2}$ can overfit instrumented variables as shown by Roodman (2009). The endogenous variable, $y_{i, t-1}$, is then replaced in the structural equation by the predicted values, $\hat{y}_{i, t-1}$.

2. In the second step, equation (1) is estimated through least squares for a fixed threshold $\gamma$ where, $y_{i, t-1}$, replaced by its predicted values from the first step regression. We can

\footnotetext{
${ }^{1}$ Note that the differences are forward-orthogonal deviations.

${ }^{2}$ Which can be $y_{i, t-2}$ to $y_{i, t-p}$ with $p=T-1$.
} 
denote the resulting sum of squares as $S(\gamma)$. This step is repeated for a strict subset of the support of the threshold variable, $f$.

3. In the third step, the estimator of threshold value is selected as the one with the smallest sum of squared residuals, i.e., $\hat{\gamma}=\operatorname{argmin} S_{n}(\gamma)$. In accordance with Hansen (1999) and Caner and Hansen (2004), the critical values for determining the 95\% confidence interval of the threshold value is given by,

$$
\Gamma=\{\gamma: \operatorname{LR}(\gamma) \geq C(\alpha)\}
$$

where $C(\alpha)$ is the $95 \%$ percentile of the asymptotic distribution of the likelihood ratio statistic $L R(\gamma)$. Once $\hat{\gamma}$ is determined, the slope of the coefficients can be estimated by the GMM for the previously used instruments and the previously estimated threshold $\hat{\gamma}$.

\section{Empirical results}

Here, we use annual data for a sample of seven ASEAN countries (Malaysia, Brunei, Indonesia, Philippines, Thailand, Singapore and Vietnam ${ }^{3}$ ) over the period spanning from 1993 to $2019^{4}$. These data are collected from various sources including the World Bank's WDI, ADB, IMF and Laeven and Valencia (2020). In their work, Laeven and Valencia (2020) provide the crisis dates of 151 systemic bank crises. They also include the dates of sovereign debt crises and currency crises. If we consider our studied sample, it seems clear that we have to take into account the impact of these crises on economic growth to isolate the effects of banking credit in these countries.

One important limitation of the approach of Kremer et al. (2013) is that the threshold variable has to be exogenous. This approach has several merits as recalled above, but controls only

\footnotetext{
${ }^{3}$ As we want a balanced panel in our empirical investigation, Myanmar, Lao PDR and Cambodia are not included in the sample due to data availability. Besides, Myanmar and Lao PDR have joined the ASEAN in 1997 and Cambodia has joined in 1999.

${ }^{4} N=n \times T=7 \times 26=182$.
} 
Table 1: Granger non-causality test results

\begin{tabular}{llll}
\hline Null hypothesis & $\bar{W}$ & $\bar{Z}$ & $\overline{\bar{Z}}$ \\
\hline$y \nrightarrow f$ & 17.5818 & 7.4825 & 0.7936 \\
& & $(0.107)$ & $(0.1660)$ \\
\hline
\end{tabular}

Notes: The null hypothesis indicates that growth per capita does not Granger-cause credit-to-GDP ratio. In the alternative, growth per capita does Granger-cause credit-to-GDP ratio for at least one country. The pvalues in parentheses are obtained through bootstrapping where 1000 replications have been used. The optimal number of lags is equal to 7 according to the Akaike information criterion.

Source: authors' calculations.

the endogeneity bias for some important regressors like initial growth in economic growth regressions. One way to circumvent this potential problem of endogeneity for the threshold variable is to follow the approach of Seo and Shin (2016) and Seo et al. (2019). In particular, Seo and Shin (2016) develop a first-differenced estimator GMM, that allows both threshold variable and regressors to be endogenous. But before considering this solution, we run the Granger non-causality tests developed by Dumitrescu and Hurlin (2012) to investigate Granger causality between growth and credit in our sample ${ }^{5}$. As we can see in Table 1, the economic growth does not Granger-cause the credit-to-GDP ratio in this sample. Thus, we can safely use the approach of Kremer et al. (2013).

The estimations of equation (1) are presented in Table 2. The threshold value for the creditto-GDP ratio $(\hat{\gamma})$ is estimated by $96.5 \%{ }^{6}$ when the likelihood ratio reaches 0 as we can observe in Figure 1 . The coefficients of the regime dependent variable, $\left(\hat{\beta}_{1}, \hat{\beta}_{2}\right)$ are positive and significant. The coefficients are fairly stable across specifications. Moreover, the below threshold coefficient is four times larger than the above one. These results means that before the turning point of credit-to-GDP $96.5 \%$ bank credit stimulates economic growth, but positive effects of bank credit expansion fade away after this threshold. Our result is consistent with previous empirical studies (Arcand et al., 2015; Cecchetti and Kharroubi, 2012; Law and Singh, 2014)

\footnotetext{
${ }^{5}$ We use the xtgcause command developed by Lopez and Weber (2017).

${ }^{6}$ The results are robust to the inclusion of dummies for banking crisis and to year dummies.
} 
that find a value for the credit-to-GDP ratio threshold which varies from $80 \%$ to $120 \%$ of GDP. However, after the threshold, bank credit still has a positive impact in our study, but this effect is largely smaller than before the threshold ${ }^{7}$.

In this sample of ASEAN countries, last year GDP growth rate does not impact the current GDP growth rate. The coefficients for control variables are correctly signed when they are significant across specifications. The $I N V$ variable always has a positive impact on short run economic and the $P O P$ variable always has a negative one.

On the one hand, the dummies for the systemic bank, currency and sovereign debt crises provide some interesting pieces of information. Indeed, the currency crises have had a very negative impact on economic growth and it is easy to infer that these results are driven by the influence of the 1997 East Asian Financial crisis. On the other hand, the time dummies ${ }^{8}$ have been included to capture common shocks on short run economic growth. As we can see again in Table 2, the time dummy for the year 2009 reflects the negative effect of the 2008 crisis on short run economic growth. Besides, the time dummy for the year 2010 indicates that these ASEAN countries have known a V-shaped recovery.

Our conclusions are more nuanced than those of Lombardi et al. (2017) who find that credit to households tends to slower economic growth when household debt-to-GDP ratio is above $80 \%$, since, on our results, an expansion of banking credit still stimulates economic growth after this threshold of $96.5 \%$. Nevertheless the positive impact of bank credit expansion is four times smaller when the credit-to-GDP ratio is above $96.5 \%$. These differences could be due to the fact that the country sample is not exactly the same in our empirical investigation.

\footnotetext{
${ }^{7}$ Our results are line with those of Botev et al. (2019) in which they cannot confirm that financial developments have a negative impact on growth beyond a given level of development using dynamic panel data threshold model which allows endogenous threshold variable and regressors (Seo and Shin, 2016; Seo et al., 2019).

${ }^{8}$ The non-significant time dummies has been removed with a general-to-specific approach.
} 
Table 2: Dynamic threshold panel regression estimation

\begin{tabular}{|c|c|c|c|}
\hline \multirow[b]{2}{*}{ Variables } & (1) & $(2)$ & (3) \\
\hline & $y_{i, t}$ & $y_{i, t}$ & $y_{i, t}$ \\
\hline Estimated threshold & 96.4703 & 96.4703 & 96.4703 \\
\hline 95\% Confidence Interval & {$[95.7289 ; 96.8323]$} & {$[95.7289 ; 96.8323]$} & [95.7289; 96.8323] \\
\hline \multicolumn{4}{|l|}{ Impact of credit } \\
\hline \multirow[t]{2}{*}{$\beta_{1}$} & $0.0742^{* * *}$ & $0.1014^{* * *}$ & $0.0871^{* * *}$ \\
\hline & $(0.0160)$ & $(0.0207)$ & $(0.0155)$ \\
\hline \multirow[t]{2}{*}{$\beta_{2}$} & $0.0145^{*}$ & $0.0265^{* * *}$ & $0.0221^{* * *}$ \\
\hline & $(0.0082)$ & $(0.0046)$ & $(0.0043)$ \\
\hline \multicolumn{4}{|l|}{ Impact of covariates } \\
\hline \multirow{2}{*}{$y_{i, t-1}$} & -0.0108 & 0.0070 & 0.1164 \\
\hline & $(0.0635)$ & $(0.0916)$ & $(0.0964)$ \\
\hline \multirow[t]{2}{*}{ INV } & $0.1276^{* *}$ & $0.1003^{* *}$ & $0.0819 * *$ \\
\hline & $(0.0600)$ & $(0.0474)$ & $(0.0389)$ \\
\hline \multirow[t]{2}{*}{ GOV } & $0.1406^{* *}$ & -0.0389 & -0.0105 \\
\hline & $(0.0547)$ & $(0.0594)$ & $(0.0427)$ \\
\hline \multirow[t]{2}{*}{ POP } & $-1.7708^{* * *}$ & $-1.8670^{* * *}$ & $-1.5593^{* * *}$ \\
\hline & $(0.6640)$ & $(0.5894)$ & $(0.6045)$ \\
\hline \multirow[t]{2}{*}{ TOT } & -0.0133 & 0.0003 & -0.0025 \\
\hline & $(0.0098)$ & $(0.0070)$ & $(0.0046)$ \\
\hline \multirow[t]{2}{*}{ OPEN } & 0.0056 & 0.0044 & 0.0050 \\
\hline & $(0.0063)$ & $(0.0060)$ & $(0.0067)$ \\
\hline \multirow[t]{2}{*}{ INFLATION } & -0.1413 & 0.0526 & -0.0173 \\
\hline & $(0.1015)$ & $(0.1165)$ & $(0.0838)$ \\
\hline \multirow[t]{2}{*}{ BANKING } & & -0.8297 & -1.1118 \\
\hline & & $(1.3528)$ & $(1.2130)$ \\
\hline \multirow[t]{2}{*}{ CURRENCY } & & $-10.2611^{* * *}$ & $-9.1433^{* * *}$ \\
\hline & & $(3.7410)$ & $(2.9663)$ \\
\hline \multirow{2}{*}{ DEBT } & & 0.6585 & 4.8154 \\
\hline & & $(4.6309)$ & $(5.9073)$ \\
\hline \multirow[t]{2}{*}{ RESTRUCTURING } & & 0.3007 & 0.5283 \\
\hline & & $(1.2002)$ & $(1.0238)$ \\
\hline \multirow[t]{2}{*}{ DUMMY_2009 } & & & $-1.6553^{* *}$ \\
\hline & & & $(0.7339)$ \\
\hline \multirow[t]{2}{*}{ DUMMY_2010 } & & & $3.0621^{* * *}$ \\
\hline & & & $(0.6271)$ \\
\hline \multirow[t]{2}{*}{ Constant } & 2.8454 & 0.6935 & 0.8903 \\
\hline & $(2.0637)$ & $(1.6413)$ & $(1.2073)$ \\
\hline Observations & 182 & 182 & 182 \\
\hline Observations above threshold & 81 & 81 & 81 \\
\hline Number of countries & 7 & 7 & 7 \\
\hline
\end{tabular}

Notes: Robust standard errors in parentheses. The symbols ${ }^{* * *},{ }^{* *}$ correspond to statistical significance at 1 and 5 percent, respectively. The non-significant time dummies has been removed with a general-to-specific approach. All differences are forward-orthogonal deviations.

Source: authors' calculations. 
Figure 1: Confidence interval construction in the threshold model

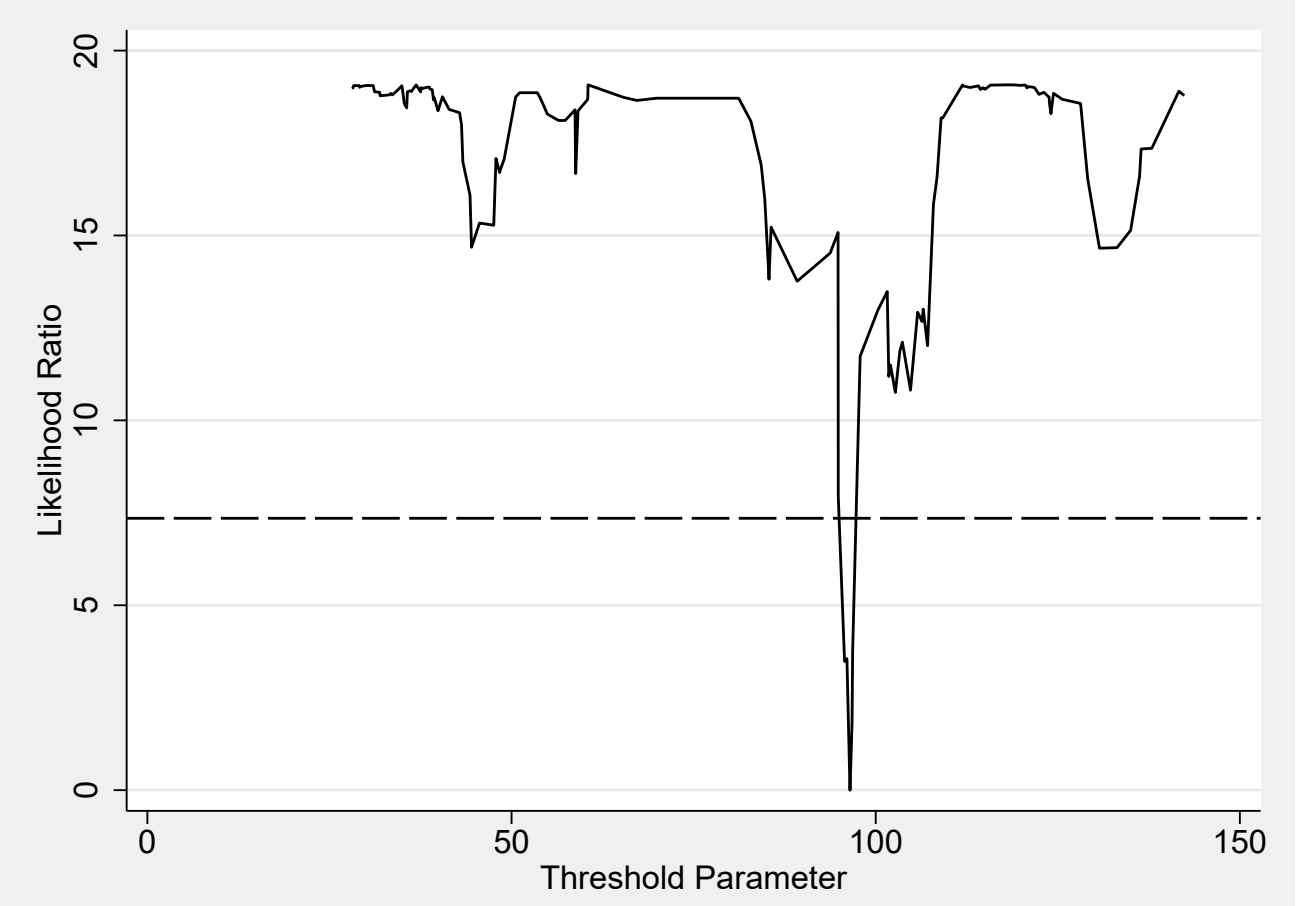

Note: The threshold estimates is the point where $L R(\gamma)$ is equal to zero. We obtain a value of 96.5 percent for the threshold.

Source: authors' calculations. 


\section{Conclusion}

This empirical investigation examines the impact of bank credit on short run economic growth, using a dynamic panel data model for ASEAN countries over the period spanning from 1993 to 2019 . We identify a credit threshold of $96.5 \%$. After this threshold, the positive effect of credit on short run economic growth is four times smaller. This threshold is lower than those of industrialized countries after World War II. An inverted L-shaped relationship suggests that positive effects of bank credit expansion on short-run economic growth fade away after this threshold. These evidence suggest that ASEAN countries have particular characteristics in their relationship between credit and short run economic growth.

\section{References}

Arcand, J.-L., E. Berkes, and U. Panizza (2015). Too much finance? Journal of Economic Growth 20(2), 105-148. Arellano, M. and O. Bover (1995). Another look at the instrumental variable estimation of error-components models. Journal of Econometrics 68(1), 29-51.

Baum, A., C. Checherita-Westphal, and P. Rother (2013). Debt and growth: New evidence for the euro area. Journal of International Money and Finance 32(C), 809-821.

Botev, J., B. Égert, and F. Jawadi (2019). The nonlinear relationship between economic growth and financial development: Evidence from developing, emerging and advanced economies. International Economics 160, $3-13$.

Caner, M. and B. E. Hansen (2004). Instrumental variable estimation of a threshold model. Econometric Theory $20(5), 813-843$.

Cecchetti, S. and E. Kharroubi (2012). Reassessing the impact of finance on growth. BIS Working Papers 381, Bank for International Settlements.

Diallo, I. A. (2020). XTENDOTHRESDPD: Stata module to estimate a Dynamic Panel Data Threshold Effects Model with Endogenous Regressors. Statistical Software Components, Boston College Department of Economics.

Dumitrescu, E.-I. and C. Hurlin (2012). Testing for Granger non-causality in heterogeneous panels. Economic Modelling 29(4), 1450-1460. 
Hansen, B. E. (1999). Threshold effects in non-dynamic panels: Estimation, testing, and inference. Journal of Econometrics 93(2), 345-368.

Kremer, S., A. Bick, and D. Nautz (2013). Inflation and growth: new evidence from a dynamic panel threshold analysis. Empirical Economics 44(2), 861-878.

Laeven, L. and F. Valencia (2020). Systemic banking crises database II. IMF Economic Review 68(2), 307-361.

Law, S. H. and N. Singh (2014). Does too much finance harm economic growth? Journal of Banking \& Finance 41(C), 36-44.

Lay, S. H. (2020). Bank credit and economic growth: Short-run evidence from a dynamic threshold panel model. Economics Letters 192(C).

Loayza, N. and R. Ranciere (2006). Financial development, financial fragility, and growth. Journal of Money, Credit, and Banking 38(4), 1051-1076.

Lombardi, M. J., M. Mohanty, and I. Shim (2017). The real effects of household debt in the short and long run. BIS Working Papers 607, Bank for International Settlements.

Lopez, L. and S. Weber (2017). Testing for Granger causality in panel data. IRENE Working Papers 17-03, IRENE Institute of Economic Research.

Narayan, P. K. and S. Narayan (2013). The short-run relationship between the financial system and economic growth: New evidence from regional panels. International Review of Financial Analysis 29, 70-78.

Roodman, D. (2009). A note on the theme of too many instruments. Oxford Bulletin of Economics and Statistics 71(1), 135-158.

Seo, M. H., S. Kim, and Y.-J. Kim (2019). Estimation of dynamic panel threshold model using Stata. The Stata Journal 19(3), 685-697.

Seo, M. H. and Y. Shin (2016). Dynamic panels with threshold effect and endogeneity. Journal of Econometrics 195(2), 169-186.

\section{Acknowledgments}

The authors are grateful to Ibrahima Amadou Diallo for making publicly available the STATA codes for estimating a dynamic panel data threshold effects model with endogenous regressors, to Samuel Ligonnière for providing us the banking crisis data, and to Katharina Priedl for proofreading. All errors or omissions are ours. 